\title{
SENSITIVITY OF SWEET POTATO GENOTYPES TO CLOMAZONE AND WEED INTERFERENCE ${ }^{1}$
}

\author{
EDSON APARECIDO DOS SANTOS ${ }^{2 *}$, VALTER CARVALHO DE ANDRADE JÚNIOR ${ }^{3}$, DANIEL JOSÉ SILVA

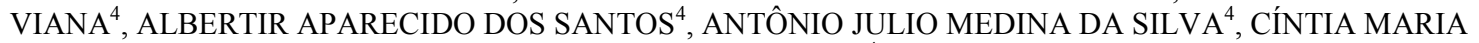 \\ TEIXEIRA FIALHO
}

\begin{abstract}
Sweet potato is a promising crop in Brazil due to its potential for bioenergy production. However, little information on adequate chemical weed control is found for this crop. Thus, the objective of this work was to evaluate the effect of clomazone on 20 genotypes of sweet potato and the sensitivity of these materials to weed interference. A field experiment was conducted using an experimental design with four blocks arranged in split-plots. The sweet potato genotypes Brazlândia-Branca, Cariru-Vermelha, Princesa, Tomba-Carro-1 and UFVJM (01, 05, 06, 07, 08, 10, 14, 23, 26, 30, 35, 42, 43, 46, 48 and 49) were grown for 180 days under three weed managements (soils treated with clomazone, mechanically weeded and with no weed control). The plots consisted of the weed control methods and the subplots consisted of the sweet potato genotypes. Phytotoxicity, branch growth and yield were evaluated. Plants grown with no weed interference had larger branch length. The highest yields were found in clomazone-treated soils. Weed interference reduced 81 to $99.7 \%$ of the yield. The less susceptible genotypes to weed interference were UFVJM07, UFVJM10 and UFVJM35, and the most sensitive were Princesa and UFVJM01. The root yield of plants under chemical weed control was similar to or greater than those with mechanical weed control in 17 of the 20 genotypes evaluated.
\end{abstract}

Keywords: Bioethanol. Herbicide. Ipomoea batata (L.) Lam.

\section{SENSIBILIDADE DE GENÓTIPOS DE BATATA-DOCE AO CLOMAZONE E À INTERFERÊNCIA DE PLANTAS DANINHAS}

\begin{abstract}
RESUMO - O cultivo de batata-doce é promissor no Brasil em função do seu potencial para produção de bioenergia. Porém, são escassas informações acerca da adequacão do controle químico de plantas daninhas na cultura. Objetivou-se avaliar o uso de clomazone no cultivo de 20 genótipos de batata-doce e a sensibilidade dos materiais à interferência de plantas daninhas. Para isso, em condições de campo, foi delineado um experimento em quatro blocos e esquematizado em parcelas subdivididas. Os genótipos Brazlândia Branca, Cariru Vermelha, Princesa, Tomba Carro1 e UFVJM (01, 05, 06 , 07, 08, 10, 14, 23, 26, 30, 35, 42, 43, 46, 48 e 49) foram cultivados por 180 dias em solo tratado com clomazone, capinado mecanicamente ou sem o controle de plantas daninhas. As formas de controle compunham as parcelas, e os genótipos foram alocados nas subparcelas. Foi avaliada a fitointoxicação, o crescimento de ramas e a produtividade. Foi observado maior comprimento de ramas quando as plantas cresceram sem a interferencia das plantas daninhas. As maiores produtividades foram conseguidas em solo tratado com clomazone e a interferência de plantas daninhas provocou reduções de 81 a 99,7\% na produtividade. Os genótipos menos sensíveis à interferência de plantas daninhas foram UFVJM07, UFVJM10 e UFVJM35, enquanto os mais sensíveis foram Princesa e UFVJM01. O controle químico proporcionou produtividade de raízes semelhante ou superior ao controle mecânico para 17 dos 20 genótipos estudados.
\end{abstract}

Palavras-chave: Bioetanol. Herbicida. Ipomoea batata (L.) Lam.

\footnotetext{
${ }^{*}$ Corresponding author

${ }^{1}$ Received for publication in $11 / 04 / 2016$; accepted in 05/01/2017.

Paper extracted from the post-doctoral report of the first author.

${ }^{2}$ Institute of Agricultural Sciences, Universidade Federal de Uberlândia, Monte Carmelo, MG, Brazil; edsonsantos@ufu.br.

${ }^{3}$ Agriculture Department, Universidade Federal de Lavras, Lavras, MG, Brazil; valter.andrade@dag.ufla.br.

${ }^{4}$ Agronomy Department, Universidade Federal dos Vales do Jequitinhonha e Mucuru, Diamantina, MG, Brazil; daniel.silva@ufvjm.edu.br, albert.ap.santos@hotmail.com, antoniojulio.medina@hotmail.com, cintiamtfialho@yahoo.com.br.
} 


\section{INTRODUCTION}

Sweet potato (Ipomoea batatas (L.) Lam. Convolvulaceae) is a very important vegetable, whose roots and branches are used as human and animal food and have higher nutritional quality and yield than several other food plants. The cultivation of sweet potato is related to the world's sustainable agriculture and fight against hunger (BOVELLBENJAMIN, 2007). Sweet potato also is important for industries, which use it as raw material to produce various foods, dyes, fabrics and cosmetics due to its high levels of starch, vitamins, fibers and proteins (OLATUNDE et al., 2016). Therefore, sweet potato is grown in more than 100 countries, making it one of the world's seven most important sources of food (FAO, 2016).

The use of sweet potatoes for ethanol production has been widely researched due to the importance of searching for renewable energy sources. Several authors report that the ethanol yield from its roots is higher than that from maize or even from sugarcane (LAREO et al., 2013; EL SHEIKHA; RAY, 2017).

Brazil is the world's second largest producer of ethanol, and the main source for its production is sugarcane (DEMIRBAS, 2017). Thus, several researchers work with the possibility of integrating sugarcane with sweet potato crops to ensure the raw material supply for bioethanol production (MANTOVANI et al., 2013; BAEYENS et al., 2015; SCHWEINBERGER et al., 2016). In this context, sweet potatoes can be grown in rotation, succession or in areas near sugarcane crops and thus, more farmers could benefit from this renewable energy production.

Sweet potato crops for ethanol production require large areas; and technical problems, such as weed control, can be a bottleneck for production. Mechanical weed control predominate in many properties, but it is an unviable practice in large areas (HARKER; O'DONOVAN, 2013). The main effective weed control used in large areas is the application of herbicides (GIANESSI, 2013). However, there are no registered herbicides in Brazil for the sweet potato crop, and information on herbicide efficacy and selectivity for this crop is scarce. Moreover, there is great genetic variability among the hundreds of sweet potato genotypes grown in Brazil (VEASEY et al., 2008; MARTINS et al., 2014). Thus, choosing for a particular genotype is difficult, since its sensitivity to weed interference and herbicides is usually unknown.

The herbicide clomazone has been successfully used in Poaceae crops, effectively controlling dozens of weeds when applied in pre or post-emergency (SHANER, 2014). Clomazone has also been well evaluated in other countries for its effectiveness in weed control in sweet potatoes (LUGO-TORRES; DÍAZ, 2007; HARRISON JR.;
JACKSON, 2011).

Considering the lack of information on the use of clomazone in sweet potato crops and the great genetic variability of the genotypes grown in Brazil, the objective of the present work was to evaluate the sensitivity of sweet potato genotypes to clomazone applied in pre-emergence and the effect of weed interference on crop yield.

\section{MATERIAL AND METHODS}

A field experiment was conducted using a completely randomized block experimental design with four blocks arranged in split-plots. The treatments consisted of 20 sweet potato genotypes of the germplasm bank of the Federal University of Jequitinhonha and Mucuri Valley (UFVJM) combined with three forms of weed management (720 $\mathrm{g} \mathrm{ha}^{-1}$ of clomazone applied at pre-emergence, mechanical weeding and no weed control). The plots consisted of the weed control methods and the subplots consisted of the sweet potato genotypes.

Eight-node cuttings were taken from the germplasm bank for seedling production and placed in a greenhouse for 30 days for rooting, using a commercial substrate in 72-cell polystyrene trays with volume of $121.2 \mathrm{~cm}^{3}$. Then, the seedlings were chosen considering the homogeneity of the plants.

The soil of the experimental field had $70 \%$ of sand, $21 \%$ of silt, $9 \%$ of clay, $2.4 \%$ of organic matter, $\mathrm{pH}\left(\mathrm{H}_{2} \mathrm{O}\right)$ of $6.3,153 \mathrm{mg} \mathrm{dm}^{-3}$ of $\mathrm{P}$, $277 \mathrm{mg} \mathrm{dm}^{-3}$ of $\mathrm{K}, 4.2 \mathrm{cmolc} \mathrm{dm}^{-3}$ of $\mathrm{Ca}^{+2}$, 0.9 cmolc $\mathrm{dm}^{-3}$ of $\mathrm{Mg}^{+2}, 0.1$ cmolc $\mathrm{dm}^{-3}$ of $\mathrm{Al}^{+3}$ and $2.7 \mathrm{cmolc} \mathrm{dm}^{-3}$ of $\mathrm{H}+\mathrm{Al}^{+3}$.

$\mathrm{N}\left(20 \mathrm{~kg} \mathrm{ha}{ }^{-1}\right), \mathrm{P}\left(40 \mathrm{~kg} \mathrm{ha}{ }^{-1}\right)$ and $\mathrm{K}$ $\left(20 \mathrm{~kg} \mathrm{ha}^{-1}\right)$ were homogeneously incorporated in the area, using a rotary hoe. Subsequently, beds (0.4 $\mathrm{m}$ high, $1.0 \mathrm{~m}$ wide and $3.0 \mathrm{~m}$ long) were prepared and arranged in rows, with spacing of $1.0 \mathrm{~m}$ between rows and $0.6 \mathrm{~m}$ between beds.

A conventional sprinkler system was used for irrigation, with water depth of $3.5 \mathrm{~mm} \mathrm{day}^{-1}$. The herbicide $\mathrm{Gamit}^{\circledR} 360 \mathrm{CS}$ (FMC; 36\% of clomazone) was applied in the plots with weed chemical control, using a backpack sprayer with pressure of $100 \mathrm{kPa}$ maintained by compressed $\mathrm{CO}_{2}$, fan-spray tips (Teejet XR8004) and flow of $150 \mathrm{~L} \mathrm{ha}^{-1}$. Environmental conditions were favorable at spraying (wind of $6.0 \mathrm{~km} \mathrm{~h}^{-1}$, relative humidity of $85 \%$ and temperature of $22.1^{\circ} \mathrm{C}$ ).

Ten seedling of each genotype per plot were transplanted to the field, spaced $0.30 \mathrm{~m}$ apart, in the first week of June 2015, one day after application (DAA) of clomazone. The genotypes used were the Brazlândia-Branca, Cariru-Vermelha, Princesa, Tomba-Carro-1 and UFVJM $(01,05,06,07,08,10$, $14,23,26,30,35,42,43,46,48$ and 49). The experimental units consisted of a subplot with 10 plants. 
$\mathrm{N}\left(20 \mathrm{Kg} \mathrm{ha}^{-1}\right)$ and $\mathrm{K}\left(20 \mathrm{Kg} \mathrm{ha}^{-1}\right)$ were applied as side dressing at 40 DAA. Weeding was carried out whenever weeds were found in treatments with mechanical weed control. Weed population was evaluated at $55 \mathrm{DAA}$, determining their density in an area of $1.0 \mathrm{~m}^{2}$ of the central portion of the experimental units, in treatments with clomazone and with no weed control.

The six central plants of each plot were considered for the evaluations. Visual symptoms of phytotoxicity by the clomazone were evaluated at 07 , 14, 28 and 56 DAA (E.W.R.C, 1964). The average branch length was evaluated at $15,45,55$ and 150 DAA and the fresh and dry (drying in a forced-air circulation oven at $65{ }^{\circ} \mathrm{C}$ for 72 hours) shoot and root yields were determined at 180 DAA.

The software $\mathrm{R}$ was used for data analysis. The data were subjected to analysis of variance and significant means were compared by the Scott-Knott test. Phytotoxicity and branch growth data were subjected to regression analysis, with graphical representation in multivariate grouping, fitting the data of each subplot to a quadratic model, using the function $l m$ of the program R. The coefficients of the fitted model of each subplot were subjected to multivariate analysis. The Tocher's optimization method was used to group the curves (CRUZ; CARNEIRO, 2006). Subsequently, the average of the treatments that composed each of the groups was considered for new data fitting grupos (FIORINI et al., 2010; LAURINDO et al., 2015). Weed density data were compared using the $\mathrm{F}$ test.

\section{RESULTS AND DISCUSSION}

The analysis of variance showed significant differences in the branch length, yield and weed density of the treatments. The application of clomazone in pre-emergence caused low visual phytotoxicity in all sweet potato genotypes, ranging from 0 to $10 \%$, with an average of $7.6 \%$, which represented no significance by the $\mathrm{F}$ test.

Lugo-Torres and Díaz (2007) evaluated eight sweet potato genotypes in Puerto Rico, with application of $1.12 \mathrm{~kg} \mathrm{ha}$ of clomazone in pre-emergence, and found no visual symptoms of phytotoxicity at 28 days after transplanting. On the other hand, Meyers et al. (2013) reported injuries in the plants caused by this herbicide, however, they found no effect on root yields. These results confirm the selectivity of this herbicide to this crop and the differences in sensitivity of each genotype.

The grouping of regression curves by the Tocher method formed 11 groups for average branch growth, which were affected by the genotype and weed control method. The group 5, formed by the genotype Brazlândia-Branca grown on soils treated with clomazone or mechanically weeded had the highest branch length (Figure 1 and Table 1).

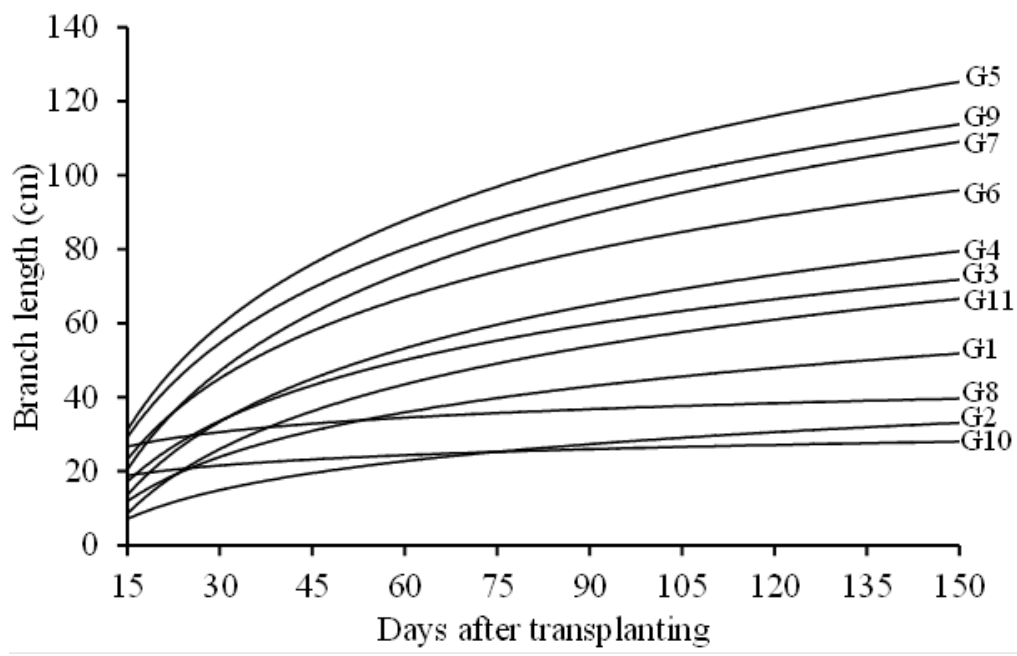

$$
\begin{aligned}
& y G 1=16.952 \ln (x)-33.126 . R^{2}=0.94 \\
& y G 2=11.007 \ln (x)-22.074 . R^{2}=0.91 \\
& y G 3=23.257 \ln (x)-44.673 . R^{2}=0.98 \\
& y G 4=28.161 \ln (x)-61.427 . R^{2}=0.99 \\
& y G 5=40.716 \ln (x)-77.911 . R^{2}=0.87 \\
& y G 6=31.015 \ln (x)-59.314 . R^{2}=0.99 \\
& y G 7=37.873 \ln (x)-80.464 . R^{2}=0.99 \\
& y G 8=5.5872 \ln (x)+11.761 . R^{2}=0.91 \\
& y G 9=36.255 \ln (x)-67.52 . R^{2}=0.99 \\
& y G 10=3.914 \ln (x)+8.420 . R^{2}=0.97 \\
& y G 11=24.675 \ln (x)-57.007 . R^{2}=0.96
\end{aligned}
$$

Figure 1. Curves after equation grouping by the Tocher test for the branch length of 20 sweet potato genotypes subjected to three methods of weed control at 15, 45, 55 and 150 days after transplanting.

The group 9, formed by the genotype UFVJM08, grown on clomazone-treated soils was the second group standing out for average branch length, followed by the group 7, formed by the genotypes Tomba-Carro-1, grown on mechanically weeded soils and Princesa, grown on clomazone-treated soils (Figure 1 and Table 1).
The average branch length of the plants in the groups 1, 2, 8 and 10, at 150 days after transplanting, was $39 \mathrm{~cm}$. These groups included all treatments with no weed control, denoting the weed interference on branch growth. Considering all plants treated with clomazone and mechanical weed control in these groups, the final average branch length was $93 \mathrm{~cm}$ (Figure 1 and Table 1). 
Table 1. Groups formed after determination of regression curves by the Tocher optimization method for the branch length of 20 sweet potato genotypes subjected to two weed control methods at 15, 45, 55 and 150 days after transplanting.

\begin{tabular}{lccc}
\hline \multirow{2}{*}{ Group } & & Weed control & no control \\
\cline { 2 - 4 } & mechanical & clomazone $\left(720 \mathrm{~g} \mathrm{ha}^{-1}\right)$ & Brazlandia Branca, Cariru \\
& Cariru Vermelha, UFVJM05, & & Vermelha, Tomba Carro1, \\
UFVJM06, UFVJM07, & & UFVJM05, UFVJM06, \\
G1 & UFVJM10, UFVJM14, & UFVJM01, UFVJM05, UFVJM07, & UFVJM07, UFVJM08, \\
& UFVJM23, UFVJM26, & UFVJM10, UFVJM23, UFVJM35, & UFVJM23, UFVJM26, \\
& UFVJM30, UFVJM35, & UFVJM42, UFVJM46, UFVJM48, & UFVJM30, UFVJM35, \\
& UFVJM42, UFVJM43, & & UFVJM42, UFVJM43, \\
G2 & UFVJM48, & UFVJM46 e UFVJM49 \\
G3 & UFVJM49, UFVJM01 & & UFVJM48, UFVJM01 e \\
G4 & Princesa & UFVJM49 & UFVJM14 \\
G5 & UFVJM46, & UFVJM26, UFVJM43, UFVJM30 & \\
G6 & Brazlandia Branca & Cariru Vermelha, UFVJM06 & \\
G7 & UFVJM08 & Brazlandia Branca & \\
G8 & Tomba Carro1 & Tomba Carro1 & Princesa \\
G9 & & Princesa & \\
G10 & & & UFVJM10 \\
G11 & & UFVJM08 & \\
\hline
\end{tabular}

Sweet potato plants are rustically grown, but they are sensitive to weed interference. The weed interference on branch length is affected by the genotype. Mechanical weed control may also decrease branch length, since it often causes damage to plants. Thus, the interaction between genotype and weed control method produces variable responses, due to the intra-specific heterogeneity of plants grown in Brazil (VEASEY et al., 2008; MARTINS et al., 2014).

Group 1 was formed by plants with no differences in branch length as a function of weed control methods. The responses of sweet potato plants to disturbance are etiolation (searching for light) and increase of number of branches, especially after mechanical damage, which often occur during mechanical weeding (RAVI; SARAVANAN, 2012). Thus, the branch length of many plants did not vary after weed control probably by this ability to respond to these disturbances.
The average plants height of plots with no weed control, at 15 days after transplanting, was approximately $19 \mathrm{~cm}$. This low branch growth formed the groups 8, 10 and part of the 1 and 2 . These plants had approximately $31 \mathrm{~cm}$ in the last evaluation, i.e., an average branch growth of approximately 1.6-fold higher. On the other hand, the average branch growth of plots with no weed interference was 5.2-fold higher, i.e., an average branch length of $15 \mathrm{~cm}$ at 15 days after transplanting and $78 \mathrm{~cm}$ at 150 days of cultivation (Figure 1 and Table 1).

These results are related to the high weed infestation of these areas. The species Amaranthus retroflexus, Bidens pilosa, Portulaca oleracea, Emilia fosrmergii, Galinsoga parviflora and Nicandra physaloides were found in all plots at high densities and they were not affected by the genotype. The average weed control of the clomazone treatment was higher than $98 \%$ (Table 2).

Table 2. Average weed density (plants $\mathrm{m}^{-2}$ ) in sweet potato beds at 55 days after transplanting and herbicide application.

\begin{tabular}{|c|c|c|c|c|c|c|}
\hline Control & $\begin{array}{c}\text { Amaranthus } \\
\text { retroflexus }\end{array}$ & $\begin{array}{l}\text { Bidens } \\
\text { pilosa }\end{array}$ & $\begin{array}{c}\text { Portulaca } \\
\text { oleracea }\end{array}$ & $\begin{array}{c}\text { Emilia } \\
\text { fosrmergii }\end{array}$ & $\begin{array}{l}\text { Galinsoga } \\
\text { parviflora }\end{array}$ & $\begin{array}{c}\text { Nicandra } \\
\text { physaloides }\end{array}$ \\
\hline No control & $188 \mathrm{a}^{*}$ & $49 \mathrm{a}$ & $587 \mathrm{a}$ & $60 \mathrm{a}$ & $132 \mathrm{a}$ & $113 \mathrm{a}$ \\
\hline Difference (\%) & 98.4 & 96.9 & 99.8 & 97.0 & 97.7 & 98.5 \\
\hline $\mathrm{CV}(\%)$ & 40.4 & 35.6 & 31.5 & 39.8 & 35.3 & 35.5 \\
\hline
\end{tabular}

Means followed by the same letter in column are not different by $\mathrm{F}$ test $(\mathrm{p}<0.01)$.

Plants of the groups 3, 4, 5, 6, 7, 9 and 11 had the highest branch lengths. These groups were formed by 16 treatments, from which 11 had plants grown on clomazone-treated soils, denoting an indirect effect of clomazone on the branch growth.
Moreover, 9 of the 20 genotypes evaluated had the same growth pattern on clomazone-treated and mechanically weeded soils (Figure 1 and Table 1).

Branch yield (fresh weight) had great variability depending on the genotypes and weed 
control methods. The highest branch yields were found with UFVJM01 (47.4 $\left.\mathrm{Mg} \mathrm{ha}^{-1}\right)$ and UFVJM46 $\left(55.6 \mathrm{Mg} \mathrm{ha}^{-1}\right)$ on clomazone-treated soils (Table 3). The genotypes Tomba-Carro-1 and UFVJM (26, 30, 42 e 46) had the greatest branch yield among plants in mechanically weeded soils, with average yield of $34.9 \mathrm{Mg} \mathrm{ha}^{-1}$. Moreover, the average branch yield under weed interference was $2.8 \mathrm{Mg} \mathrm{ha}^{-1}$, with no significant difference between genotypes (Table 3 ).

Table 3. Branch yield of sweet potato genotypes after 180 days of cultivation under two weed control methods.

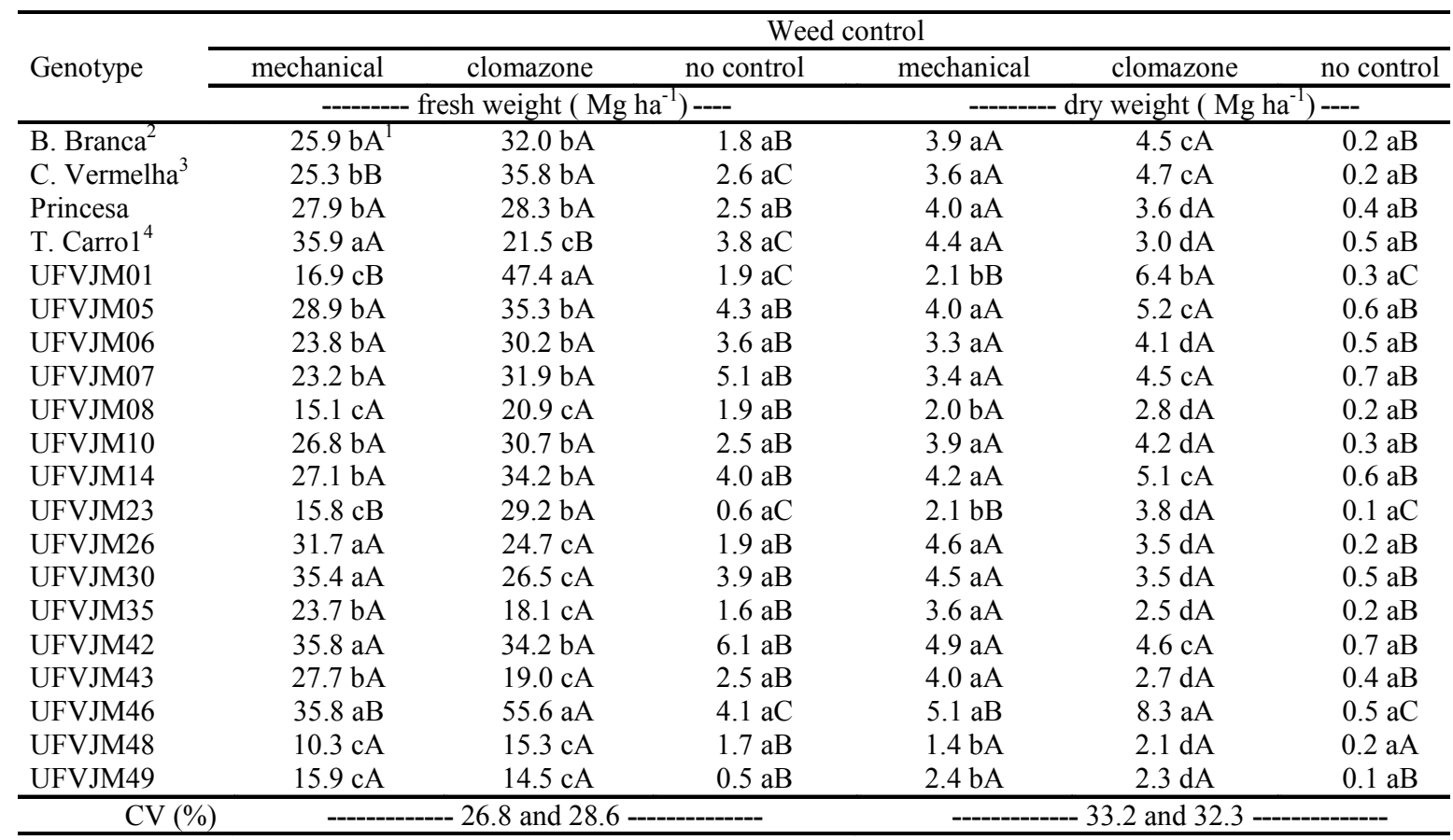

${ }^{1}$ Means followed by the same letter, lower case in column and upper case in line, are not different by Scott Knott criteria $(\mathrm{p}<0.05) .{ }^{2}$ Brazlândia Branca, ${ }^{3}$ Cariru Vermelha, ${ }^{4}$ Tomba Carro 1.

The average branch yield of the genotypes Cariru-Vermelha and UFVJM $(01,23$ and 46) grown on clomazone-treated soils was $42 \mathrm{Mg} \mathrm{ha}^{-1}$. These same genotypes had average branch yield of $23.4 \mathrm{Mg} \mathrm{ha}^{-1}$ when grown on mechanically weeded soils (Table 3).

The branch yield of plants on mechanically weeded soils (2.9 $\left.\mathrm{Mg} \mathrm{ha}^{-1}\right)$ and clomazone-treated soils (25.8 $\left.\mathrm{Mg} \mathrm{ha}^{-1}\right)$ were similar in 15 of the 20 genotypes (Table 3 ).

Plants grown on clomazone-treated soils had higher branch dry weights compared with those gown on mechanically weeded soils. The genotype UFVJM46, grown on clomazone-treated soils had the highest branch dry weight $\left(8.3 \mathrm{Mg} \mathrm{ha}^{-1}\right)$. Moreover, the branch dry weights of the genotypes UFVJM $(01,23$ e 46) grown on clomazone-treated soils was higher than those of plants under the other weed control methods. Fifteen genotypes grown on mechanically weeded soils had the highest average branch dry weight (4.1 $\left.\mathrm{Mg} \mathrm{ha}^{-1}\right)$. Plants with no weed control had average branch dry weight of $0.37 \mathrm{Mg} \mathrm{ha}^{-1}$, regardless of the genotype (Table 3 ).

Mechanical weed control causes direct damages to sweet potato plants and generates indirect damages by its costs and time consumed (HARKER; O'DONOVAN, 2013). Therefore, the use of clomazone in pre-emergence is a promising chemical weed control method to the genotypes evaluated when they are intended for branch dry weight production.

Some of the genotypes that were less affected by weed interference may be recommended for areas with high weed densities. The genotypes TombaCarro-1 and UFVJM43 can be considered less sensitive to the weed interference, since their branch yield loss was $15 \%$ lower than those of the genotypes UFVJM23 and UFVJM49, which had up to $98 \%$ of their yield compromised by weed interference (Table 3).

The genotype UFVJM01 grown on clomazone-treated soils had the highest fresh root weight (root yield), with production over $62 \mathrm{Mg} \mathrm{ha}^{-1}$, which was $100 \%$ higher than its root yield when it was grown on mechanically weeded soils. Moreover, the root yield of the genotypes Cariru-Vermelha and UFVJM46 grown on clomazone-treated soils increased 18.4 and $16.2 \mathrm{Mg} \mathrm{ha}{ }^{-1}$ respectively, compared with those found on mechanically weeded soils (Table 4). 
E. A. SANTOS et al.

Table 4. Fresh root weight of sweet potato genotypes after 180 days of cultivation under different weed control methods.

\begin{tabular}{|c|c|c|c|c|c|c|}
\hline \multirow{3}{*}{ Genotype } & \multicolumn{6}{|c|}{ Weed control } \\
\hline & mechanical & clomazone & no control & mechanical & clomazone & no control \\
\hline & \multicolumn{3}{|c|}{------- fresh weight $\left(\mathrm{Mg} \mathrm{ha}^{-1}\right)$------ } & \multicolumn{3}{|c|}{------ dry weight $\left(\mathrm{Mg} \mathrm{ha}^{-1}\right)$------- } \\
\hline B. branca ${ }^{2}$ & $24.8 \mathrm{cA}^{1}$ & $23.0 \mathrm{dA}$ & $1.2 \mathrm{aB}$ & $6.8 \mathrm{cA}$ & $6.6 \mathrm{cA}$ & $0.33 \mathrm{aB}$ \\
\hline C. vermelha ${ }^{3}$ & $33.1 \mathrm{bB}$ & $51.5 \mathrm{bA}$ & $2.7 \mathrm{aC}$ & $9.1 \mathrm{bB}$ & $13.3 \mathrm{aA}$ & $0.75 \mathrm{aC}$ \\
\hline Princesa & $32.7 \mathrm{bA}$ & $40.5 \mathrm{cA}$ & $1.0 \mathrm{aB}$ & $8.2 \mathrm{bA}$ & $10.7 \mathrm{bA}$ & $0.28 \mathrm{aB}$ \\
\hline T. carro $1^{4}$ & $46.8 \mathrm{aA}$ & $32.3 \mathrm{cB}$ & $2.1 \mathrm{aC}$ & $12.2 \mathrm{aA}$ & $8.5 \mathrm{bB}$ & $0.57 \mathrm{aC}$ \\
\hline UFVJM01 & $31.2 \mathrm{bB}$ & $62.7 \mathrm{aA}$ & $0.1 \mathrm{aC}$ & $7.9 \mathrm{bB}$ & $14.1 \mathrm{aA}$ & $0.02 \mathrm{aC}$ \\
\hline UFVJM05 & $20.8 \mathrm{cA}$ & $18.5 \mathrm{dA}$ & $1.4 \mathrm{aB}$ & $5.8 \mathrm{cA}$ & $5.2 \mathrm{cA}$ & $0.53 \mathrm{aB}$ \\
\hline UFVJM06 & $22.4 \mathrm{cA}$ & $24.0 \mathrm{dA}$ & $2.9 \mathrm{aB}$ & $5.6 \mathrm{cA}$ & $6.3 \mathrm{cA}$ & $0.80 \mathrm{aB}$ \\
\hline UFVJM07 & $18.5 \mathrm{dA}$ & $16.4 \mathrm{eA}$ & $2.4 \mathrm{aB}$ & $5.5 \mathrm{cA}$ & $4.5 \mathrm{cA}$ & $0.64 \mathrm{aB}$ \\
\hline UFVJM08 & $33.4 \mathrm{bA}$ & $36.1 \mathrm{cA}$ & $2.0 \mathrm{aB}$ & $8.0 \mathrm{bA}$ & $10.1 \mathrm{bA}$ & $0.59 \mathrm{aB}$ \\
\hline UFVJM10 & $13.4 \mathrm{dA}$ & $12.4 \mathrm{eA}$ & $2.3 \mathrm{aB}$ & $4.0 \mathrm{cA}$ & $3.7 \mathrm{dA}$ & $0.55 \mathrm{aB}$ \\
\hline UFVJM14 & $41.4 \mathrm{aA}$ & $22.5 \mathrm{~dB}$ & $2.6 \mathrm{aC}$ & $11.7 \mathrm{aA}$ & $7.0 \mathrm{cB}$ & $0.82 \mathrm{aC}$ \\
\hline UFVJM23 & $24.7 \mathrm{cA}$ & $21.9 \mathrm{dA}$ & $1.0 \mathrm{aB}$ & $7.3 \mathrm{cA}$ & $6.0 \mathrm{cA}$ & $0.28 \mathrm{aB}$ \\
\hline UFVJM26 & $17.5 \mathrm{dA}$ & $14.7 \mathrm{eA}$ & $4.3 \mathrm{aB}$ & $5.4 \mathrm{cA}$ & $4.5 \mathrm{cA}$ & $1.22 \mathrm{aB}$ \\
\hline UFVJM30 & $23.1 \mathrm{cA}$ & $30.4 \mathrm{cA}$ & $1.6 \mathrm{aB}$ & $5.8 \mathrm{cB}$ & $9.3 \mathrm{bA}$ & $0.41 \mathrm{aC}$ \\
\hline UFVJM35 & $12.2 \mathrm{dA}$ & $8.4 \mathrm{eA}$ & $1.3 \mathrm{aB}$ & $3.7 \mathrm{cA}$ & $3.5 \mathrm{dA}$ & $0.34 \mathrm{aB}$ \\
\hline UFVJM42 & $22.6 \mathrm{cA}$ & $14.8 \mathrm{eA}$ & $1.7 \mathrm{aB}$ & $7.2 \mathrm{cA}$ & $4.8 \mathrm{cA}$ & $0.53 \mathrm{aB}$ \\
\hline UFVJM43 & $14.9 \mathrm{dA}$ & $10.7 \mathrm{eA}$ & $1.2 \mathrm{aB}$ & $4.6 \mathrm{cA}$ & $3.5 \mathrm{dA}$ & $0.39 \mathrm{aB}$ \\
\hline UFVJM46 & $17.3 \mathrm{~dB}$ & $33.5 \mathrm{cA}$ & $1.0 \mathrm{aC}$ & $5.0 \mathrm{cB}$ & $10.0 \mathrm{bA}$ & $0.29 \mathrm{aC}$ \\
\hline UFVJM48 & $26.3 \mathrm{cA}$ & $31.0 \mathrm{cA}$ & $0.9 \mathrm{aB}$ & $7.2 \mathrm{cA}$ & $8.9 \mathrm{bA}$ & $0.21 \mathrm{aB}$ \\
\hline UFVJM49 & $14.2 \mathrm{dA}$ & $6.8 \mathrm{eB}$ & $0.5 \mathrm{aB}$ & $4.2 \mathrm{cA}$ & $1.9 \mathrm{~dB}$ & $0.15 \mathrm{aB}$ \\
\hline
\end{tabular}

${ }^{1}$ Means followed by the same letter, lower case in column and upper case in line, are not different by Scott Knott criteria $(\mathrm{p}<0.05) .{ }^{2}$ Brazlândia Branca, ${ }^{3}$ Cariru Vermelha, ${ }^{4}$ Tomba Carro1.

The genotypes Tomba-Carro-1 and UFVJM14 had the highest root yield among those grown on mechanically weeded soils, with root yield average of $44.1 \mathrm{Mg} \mathrm{ha}^{-1}$. The root weights of these genotypes, together with the UFVJM49, was higher when grown on mechanically weeded soils compared with those when they were grown on clomazone-treated soils (Table 4).

The low root yield of the genotypes Cariru-Vermelha, UFVJM01 and UFVJM46 was related to the harmful effect caused by mechanical weed control on their shoots (Table 3 ). On the other hand, although the genotype UFVJM23 had lower branch yield under mechanical weed control, it showed similar root yield on clomazone-treated soils (Table 3). Clomazone decreased the fresh branch and root yields of the genotype Tomba-Carro-1 (Tables 3 and 4). The genotypes evaluated showed genetic similarity and positive correlations between shoot and root biomass accumulations (AZEVEDO et al., 2015). However, according to the phytotechnical characters evaluated the environment is the main factor affecting the yield of these plants.

The fresh root yield of plants under mechanically weeded and clomazone-treated soils were similar in 14 of the 20 genotypes (Table 3). The average fresh root yield of these genotypes was $22 \mathrm{Mg} \mathrm{ha}{ }^{-1}$. Plants under no weed control had average fresh root yield of $1.7 \mathrm{Mg} \mathrm{ha}^{-1}$, regardless of the genotype (Table 4).

Weed interference affected fresh root yield differently, depending on the genotype. Regarding the use of clomazone, UFVJM10 showed $81 \%$ of decrease in the yield potential, while UFVJM07 and UFVJM35 showed $85 \%$ (Table 4), being considered the least sensitive genotype to weed interference. On the other hand, the genotypes Princesa and UFVJM01 showed reductions of 98 and $99.7 \%$ (Table 4), respectively, being considered the most sensitive to interference.

The tolerance to weed interference is affected by the growth habit of the sweet potato plants. Plants with more vigorous initial growth, shorter and more upright branches are more tolerant. Moreover, many plants are able to produce well, even under presence of weeds, due to the variability among cultivars (HARRISON JR; JACKSON, 2011).

The genotypes Cariru-Vermelha and UFVJM01 on clomazone-treated soils had the highest root dry weights, with average of 13.7 $\mathrm{Mg} \mathrm{ha} \mathrm{ha}^{-1}$ (Table 4). On mechanically weeded soils, the genotypes Tomba-Carro-1 and UFVJM14 had the highest root dry weights, with average of $11.9 \mathrm{Mg} \mathrm{ha}^{-1}$. The root dry weight of plants under weed interference was $0.48 \mathrm{Mg} \mathrm{ha}^{-1}$ (Table 4).

The genotypes Cariru-Vermelha and UFVJM $(01,30$ e 46) had higher yields with clomazone application than with mechanical weed control. On the other hand, Tomba-Carro-1, UFVJM14 and UFVJM49 were more productive in mechanically weeded soils (Table 4).

The root dry weight is determinant of fuel yield when using sweet potato for bioethanol production (LAREO et al., 2013), thus, the use of clomazone is promising to optimize root production, since its weed control was similar to mechanical 
weed control and beneficial for root production in 17 of the 20 genotypes evaluated. The characterization of genotypes in terms of sensitivity to weed interference and to the herbicide clomazone is useful for choosing parent materials for sweet potato breeding programs.

\section{CONCLUSIONS}

The use of the herbicide clomazone provided greater or similar branch yield to mechanical weed control in 19 of the 20 sweet potato genotypes evaluated and greater or similar root yield to mechanical weed control in 17 genotypes. Weed interference causes reductions of 81 to $99.7 \%$ in plant yield. The genotypes less sensitive to weed interference were UFVJM07, UFVJM10 and UFVJM35, while the most sensitive genotypes were Princesa and UFVJM01.

\section{ACKNOWLEDGMENTS}

The authors are grateful to FAPEMIG, CAPES and CNPq for the financial support.

\section{REFERENCES}

AZEVEDO, A. M. et al. Desempenho agronômico e parâmetros genéticos em genótipos de batata-doce. Horticultura Brasileira, Brasília, v. 33, n. 1, p. 8490, 2015.

BAEYENS, J. K. et al. Challenges and opportunities in improving the production of bio-ethanol. Progress in Energy and Combustion, Stanford, v. 47, n. 3, p. 60-88, 2015.

BOVELL-BENJAMIN, A. C. Sweet Potato: A Review of its Past, Present, and Future Role in Human Nutrition. Advances in Food and Nutrition Research, Valencia, v. 52, n. 6, p. 1-59, 2007.

CRUZ, C. D.; CARNEIRO, P. C. S. Modelos biométricos aplicados ao melhoramento genético. 2. ed. Viçosa, MG: UFV, 2006. 585 p.

DEMIRBAS, A. Tomorrow's biofuels: Goals and hopes. Energy Sources, Part A: Recovery, Utilization, and Environmental Effects, Laramie, v. 39, n. 7, p. 673-679, 2017.

EL SHEIKHA, A. F.; RAY, R. C. Potential Impacts of Bio-processing of Sweet Potato: Review. Critical Reviews in Food Science and Nutrition, Amherst, v. 57 , n. 3 , p. $455-471,2017$.
E.W.R.C. Report of 3rd and 4rd meetings of E.W.R.C. Cittee of methods in weed research. Weed Research, Bachlaan, v. 4, n. 1, p. 88, 1964.

FIORINI, C. V. A. et al. Agrupamento de curvas de progresso de requeima em tomateiro originado de cruzamento interespecífico. Pesquisa Agropecuária Brasileira, Brasília, v. 45, n. 2, p. 1095-1101, 2010.

FOOD AND AGRICULTURE ORGANIZATION OF THE UNITED NATIONS - FAO. FAOSTAT. Disponível em: <http://faostat.fao.org/site/567/ DesktopDefault.aspx?PageID $=567$ \#ancor $>$. Acesso em: 22 de set. 2016

GIANESSI, P. L. The Increasing Importance of Herbicides in Worldwide Crop Production. Pest Management Science, Oxford, v. 69, n. 10, p. 1099$1105,2013$.

HARKER, K. N.; O'DONOVAN, J. T. Recent Weed Control, Weed Management, and Integrated Weed Management. Weed Technology, Lawrence, v. 27, n. 1, p. 1-11, 2013.

HARRISON JR. H. F.; JACKSON, D. M. Response of two sweet potato cultivars to weed interference. Crop Protection, Queensland, v. 30, n. 10, p. 12911296, 2011.

LAREO, C. et al. Evaluation of sweet potato for fuel bioethanol production: hydrolysis and fermentation. SpringerPlus, Heidelberg, v. 2, n. 493, p. 1-11, 2013.

LAURINDO, B. S. et al. Seleção de acessos de tomateiro resistentes à pinta-preta pela análise de agrupamento das curvas de progresso da doença. Pesquisa Agropecuária Brasileira, Brasília, v. 50, n. 4, p. 106-114, 2015.

LUGO-TORRES, M. L. L.; DÍAZ, M. Weed control in sweet potato. The Journal of Agriculture of the University of Puerto Rico, Bayamón, v. 91, n. 3-4, p. 1-11, 2007.

MANTOVANI, E. C. et al. Eficiência no uso da água de duas cultivares de batata-doce em resposta a lâminas de irrigação. Horticultura Brasileira, Brasília, v. 31, n. 2, p. 602-606, 2013.

MARTINS, E. C. A. et al. Genetic diversity in sweet potato in tocantins. Bioscience Journal, Uberlândia v. 30, n. 2 , p. $429-435,2014$

MEYERS, S. L. et al. Herbicide-Based Weed Management Programs for Palmer Amaranth in Sweetpotato. Weed Technology, Lawrence, v. 27, n. 2, p. 331-340, 2013. 
OLATUNDE, G. O. et al. Quality attributes of sweet potato flour as influenced by variety, pretreatment and drying method. Food and Sciente Nutrition, Leeds, v. 4, n. 4, p. 623-635, 2016.

RAVI, V.; SARAVANAN, R. Crop Physiology of Sweetpotato. Fruit, Vegetable and Cereal Sciente and Biotecnology, Thiruvananthapuram, v. 6, s/n., p. 17-29, 2012.

SCHWEINBERGER, C. M. et al. Ethanol production from sweet potato: The effect of ripening, comparison of two heating methods, and cost analysis. The Canadian Journal of Chemical Engineering, Edmonton, v. 94, n. 4, p. 716-724, 2016.

SHANER, D. L. Herbicide Handbook. 10. ed. Lawrence, KS: Weed Science Society of America, 2014. 349 p.

VEASEY, E. A. et al. Genetic diversity in Brazilian sweet potato (Ipomoea batatas (L.) Lam., Solanales, Convolvulaceae) landraces assessed with microsatellite markers. Genetic and Molecular Biology, Ribeirão Preto, v. 31, n. 3, p. 725-733, 2008. 